\title{
COMPARISON BETWEEN THE DESIGN LATERAL LOADS ON R.C. HIGH RISE BUILDINGS ACCORDING TO THE RECENT EGYPTIAN CODES
}

\author{
Nageh N. Meleka \\ Civil Engineering Department, Faculty of Engineering, \\ Minoufiya University, Shebin El-Kom, Egypt
}

\begin{abstract}
The main loads acting on any building are the vertical and the lateral loads. Lateral loads are induced mainly from the wind and the earthquakes and should be considered in the design of reinforced concrete structures, especially for high-rise buildings. Great modifications were introduced to the previous Egyptian code of practice for calculating loads and forces in structural and building works 1993, ECOP-93. The new Egyptian code ECOP-201, 2003 introduced the method of spectrum analysis for calculating seismic loads instead of the previous simplified method. In many cases effects of earthquakes are found to be dominant and more critical than wind effects. This depends on some factors defined by the codes. In this research the latest code is reviewed for wind and earthquake analysis and discussed to show all factors affecting the design. A computer program is developed to analyze the structural buildings subjected to wind pressure and the equivalent loads of earthquakes defined by the two Egyptian codes. Numerical examples are solved, analyzed discussed and compared for different factors. The main conclusions are summarized.
\end{abstract}

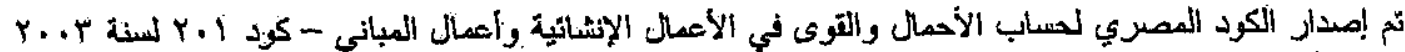

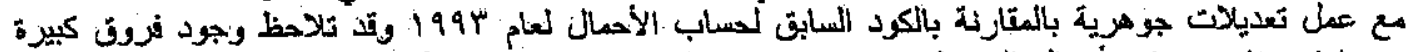

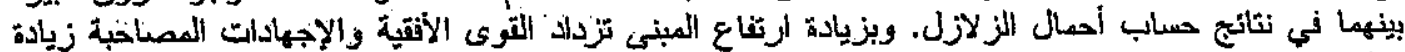

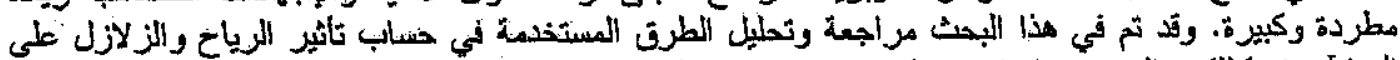

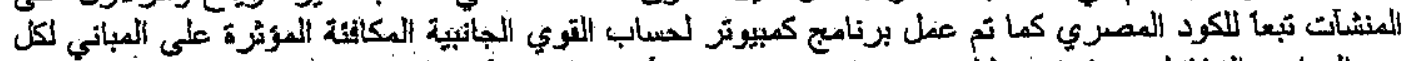

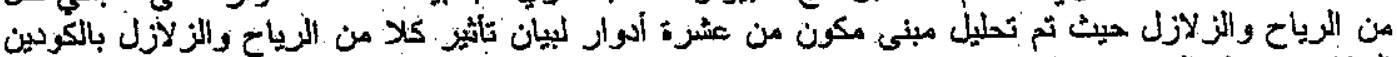

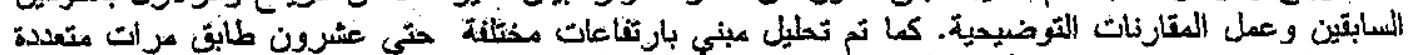

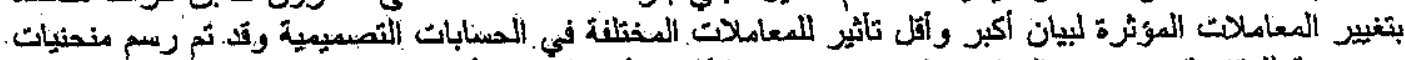

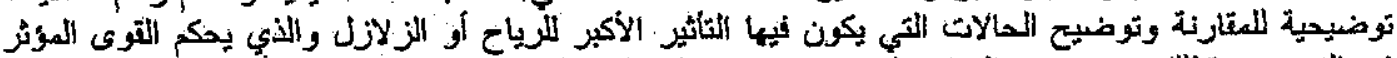

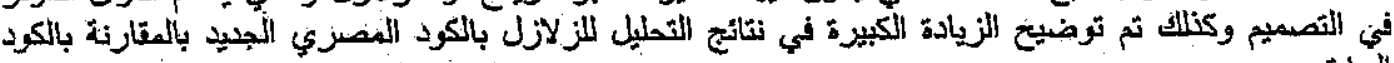

Keywords: High-rise buildings, Egyptian code, wind pressure, equivalent static loads, computer analysis.

\section{INTRODUCTION}

Great changes - were introduced in the latest Egyptian code of practice for calculating loads and forces in structural and building works 2003, ECOP$201[1]$, with respect to the previous code, ECOP$93[2,3]$. These changes lead to great differences between the results of the two codes in case of calculating the equivalent loads for earthquakes.

In order to design a structure to resist wind and earthquake effects, the forces on the structure must be specified. The exact forces that will occur during the life of the structure cannot be known [4]. Most National building codes identify some factors according to the boundary conditions of each building considered in the analysis to provide the life safety but not to insure against damage [5,6]. A realistic estimate for these factors is important; however the cost of construction and therefore the economic viability of the project is essential.

The ECOP-201 gives a great concentration on calculating. these loads and the corresponding additional stresses to be taken into account in the design of the structures. The new code introduces different factors for wind and earthquake that govern the design and influence the results. 


\section{REVISION OF ECOP -201}

2.1 Wind Loads

No changes were introduced to the previous code ECOP- 93. The code identifies the pressure or the suction induced by the wind from the following equation:

$$
P_{e}=c_{e} k q
$$

Where,

$\mathrm{P}_{\mathrm{e}}=$ external design wind pressure affecting statically on the unit area of the external surfaces of the building.

$\mathrm{q}=$ original wind pressure depends on the geographic site, Table (7-1) [1].

$k=$ factor of exposure defines the distribution of the wind according to the height of the building from the ground surface, Table (7-2) [1].

$c_{e}=$ pressure or suction distribution factor on the external surface of the building.
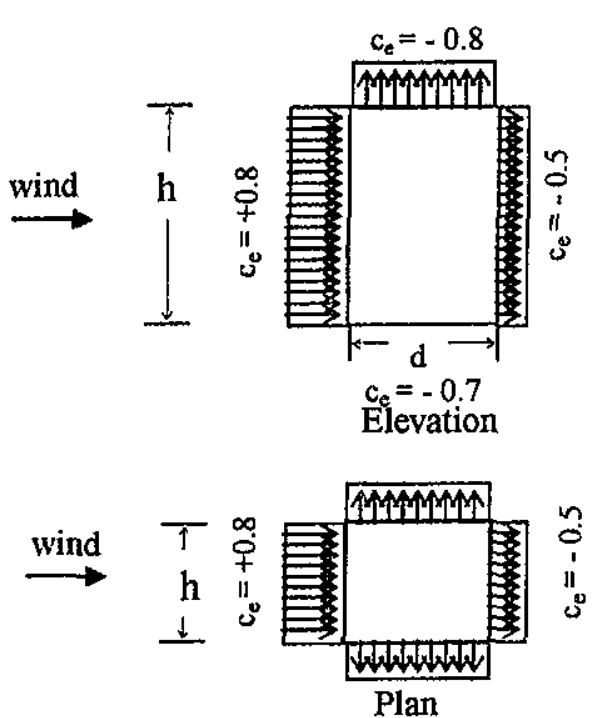

Fig. 1 Factors of pressure distribution on the external surface of the building

\subsection{Seismic Analysis}

The ultimate base shear force is calculated at each direction by the formula:

$$
F_{b}=\gamma_{I} S_{d}\left(T_{I}\right) \lambda W / g
$$

Where,

$\gamma_{1}$ is importance factor:

$\gamma_{\mathrm{I}}=1.4$ (buildings for emergency purposes),

$=1.2$ (important buildings),

$=1.0$ (for other buildings).

$=0.8$ (for less important buildings).

$\mathrm{T}_{\mathrm{I}}$ is the fundamental period of the building in sec.

$T_{I}=C_{t} H^{(3 / 4)}$ for buildings up to $60 \mathrm{~m}$,

$\mathrm{H}=$ Height of the building,

$C_{t}=0.075$ for RC space frames,
$C_{t}=0.05$ for other systems for shear walls,

or $\quad C_{t}=0.075 \sqrt{A_{C}} \quad$ and

$A_{C}=\sum\left[A_{i}\left\{0.2+\left(L_{w i} / H\right)\right\}^{2}\right]$

and

$\mathrm{L}_{\mathrm{wi}} / \mathrm{H} \leq 0.9$

$\mathrm{S}_{\mathrm{d}}\left(\mathrm{T}_{\mathrm{I}}\right)$ is the horizontal design spectrum for elastic analysis

$0 \leq \mathrm{T} \leq \mathrm{T}_{\mathrm{B}}: \mathrm{S}_{\mathrm{d}}(\mathrm{T})=\mathrm{a}_{\mathrm{g}} \mathrm{S}\left[1+\frac{\mathrm{T}}{\mathrm{T}_{\mathrm{B}}}\left(\frac{2.5 \eta}{\mathrm{R}}-1.0\right)\right]$

$\mathrm{T}_{\mathrm{B}} \leq \mathrm{T} \leq \mathrm{T}_{\mathrm{C}}: \mathrm{S}_{\mathrm{d}}(\mathrm{T})=\mathrm{a}_{\mathrm{g}} \mathrm{S} \frac{2.5}{\mathrm{R}} \eta$

$\mathrm{T}_{\mathrm{C}} \leq \mathrm{T} \leq \mathrm{T}_{\mathrm{D}}: \mathrm{S}_{\mathrm{d}}(\mathrm{T})=\mathrm{a}_{\mathrm{g}} \quad \mathrm{S} \frac{2.5}{\mathrm{R}}\left[\frac{\mathrm{T}_{\mathrm{C}}}{\mathrm{T}}\right]$,

$$
\eta \geq[0.2] \mathrm{a}_{\mathrm{g}}
$$

$$
\begin{aligned}
& \mathrm{T}_{\mathrm{D}} \leq \mathrm{T} \leq 4 \sec : \mathrm{S}_{\mathrm{d}}(\mathrm{T})=\mathrm{a}_{\mathrm{g}} \quad \mathrm{S} \frac{2.5}{\mathrm{R}}\left[\frac{\mathrm{T}_{\mathrm{C}}}{\mathrm{T}}\right], \\
& \eta \geq[0.2] \mathrm{a}_{\mathrm{g}} .
\end{aligned}
$$

Where,

$\mathrm{a}_{\mathrm{g}}$ is the design ground acceleration

$\mathrm{a}_{\mathrm{g}}=0.10 \mathrm{~g}, 0.15 \mathrm{~g}, 0.2 \mathrm{~g}, 0.25 \mathrm{~g}$ for zone $1,2,3,4,5$ respectively.

$S=$ soil factor and is given in Table 8.1[1], the value of the soil factor is defined according to subsoil class A, B, C, D as described in Table 8.1[1].

$T_{B}, T_{C}, T_{D}$ are factors according to subsoil class, given in Table 8.2[1].

$\mathrm{R}=$ response modification (force reduction) factor

$R=4.5$ for $R C$ shear walls,

$=5.0$ for limited ductile frames,

$=5.0$ for combined system from $\mathrm{RC}$ frames and $\mathrm{RC}$ shear walls ,

$=2.0$ for elevated tanks over frames,

$=3.5$ for silos and chimney.

$\eta=$ horizontal damping factor $=1$ for reinforced concrete

$\eta_{v}=$ vertical damping factor $=1$ for reinforced concrete

$\mathrm{W}=$ total building weight over the foundations

$W=D L+L L$ for Silos, tanks, libraries, store houses, garages ....etc.

$=\mathrm{DL}+0.5 \mathrm{LL}$ for other buildings

$\mathrm{g}=$ ground acceleration $=981 \mathrm{~cm} / \mathrm{sec}^{2}$

$\lambda=$ correction factor:

$$
\begin{array}{ll}
\mathrm{T}_{1} \leq 2 \mathrm{~T}_{\mathrm{C}}: & \lambda=0.85, \\
\mathrm{~T}_{1}>2 \mathrm{~T}_{\mathrm{C}}: & \lambda=1.0
\end{array}
$$

The total seismic shear force $\mathrm{Fb}$ is divided into static forces $\mathrm{Fj}$ acting at the level of each floor at the center of mass by the following equation: 


$$
F_{j}=F_{b} \frac{w_{j} H_{j}}{\sum_{i=1}^{n} W_{i} H_{i}}
$$

Where $W_{j}=$ design weight of the floor $j$ :

$$
\mathrm{H}_{\mathrm{j}}=\text { height of the floor } \mathrm{j} \text { from the base. }
$$

The story shear force at any floor (j) is the sum of the lateral forces at and above this level:

$$
F_{j}=\sum_{i=j}^{n} F_{i}
$$

The overturning moment at a particular floor (j):

$$
\mathrm{M}_{\mathrm{j}}=\sum_{i=j}^{n} \mathrm{~F}_{\mathrm{i}}\left(\mathrm{H}_{\mathrm{i}}-\mathrm{H}_{\mathrm{j}}\right)
$$

In-plane forces in èach column or wall due to direct shear are computed from:

$$
\mathrm{V}_{\mathrm{bx}}=\mathrm{F}_{\mathrm{bx}} \frac{\mathrm{K}_{\mathrm{x}}}{\sum \mathrm{K}_{\mathrm{x}}}, \mathrm{V}_{\mathrm{vy}}=\mathrm{F}_{\mathrm{yy}} \frac{\mathrm{K}_{\mathrm{y}}}{\sum \mathrm{K}_{\mathrm{y}}}
$$

Where, $K_{x}, K_{y}=$ stiffness of each vertical meimber resisting lateral load in $\mathrm{X}$ and $\mathrm{Y}$ directions respectively.

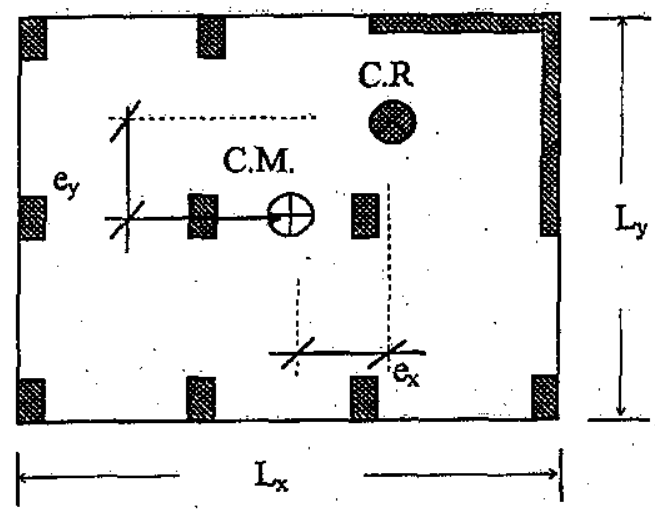

Fig. 2 Center of mass and center of rigidity

A torsional moment $\mathrm{M}_{\mathrm{t}}$ results from the eccentricity between the center of mass (C.M.)

and the center of rigidify (C.R.) :

where C.M. = center of mass at $\left(\mathrm{x}_{\mathrm{m}}, \mathrm{y}_{\mathrm{m}}\right)$ :

$$
\mathrm{x}_{\mathrm{m}}=\frac{\sum \mathrm{p} . \mathrm{x}}{\Sigma \mathrm{P}}, \mathrm{y}_{\mathrm{m}}=\frac{\sum \mathrm{P} \cdot \mathrm{y}}{\sum \mathrm{P}}
$$

$P=$ represents the reaction of each column or wall, and

C.R. = center of rigidities and is located at $\left(\mathrm{x}_{\mathrm{r}}, \mathrm{y}_{\mathrm{f}}\right)$ :

$$
\mathrm{x}_{\mathrm{r}}=\frac{\sum \mathrm{K}_{\mathrm{y}} \cdot \mathrm{x}}{\sum \mathrm{K}_{\mathrm{y}}} ; \mathrm{y}_{\mathrm{r}}=\frac{\sum \mathrm{K}_{\mathrm{x}} \cdot \mathrm{y}}{\sum \mathrm{K}_{\mathrm{x}}}
$$

$\mathrm{K}_{\mathrm{x}}, \mathrm{K}_{\mathrm{y}}=$ represents the stiffness of each column or wall

The eccentricity of the building is defined as:

$$
e_{x}=x_{r}-x_{m}, e_{y}=y_{r}-y_{m}
$$

The Egyptian code specifies the design eccentricity $\left(e_{x d}, e_{y d}\right)$ as follows:

$$
\begin{aligned}
& e_{x d}=\text { the max of } e_{x}=x_{r}-x_{m} \pm 0.05 L_{x} \\
& e_{y d}=\text { the max of } e_{y}=y_{r}-y_{m} \pm 0.05 L_{y}
\end{aligned}
$$

The torsional moment is calculated from the following formula:

$$
\mathrm{M}_{\mathrm{tx}}=\mathrm{F}_{\mathrm{bx}} e_{\mathrm{yd}}, \mathrm{M}_{\mathrm{ty}}=\mathrm{F}_{\mathrm{by}} \mathrm{e}_{\mathrm{xd}}
$$

The in-plane force on each column or wall due to torsion results from the eccentricity between the center of mass (C.M.) and the center of rigidity (C,R.) at any level are computed from:

$$
F_{t x}=M_{t x} \cdot \frac{K_{x} d_{x}}{J_{r}}, F_{t y}=M_{t y} \frac{K_{y} d_{y}}{J_{r}}
$$

where $d_{x}, d_{y}=$ are the distances of each column or wall from the center of rigidity .

$$
\mathrm{J}_{\mathrm{r}}=\text { Torsional stiffness }=\sum \mathrm{K}_{\mathrm{x}} \mathrm{d}_{\mathrm{x}}^{2}+\mathrm{K}_{\mathrm{y}} \mathrm{d}_{\mathrm{y}}^{2}
$$

Member stiffness is considered as a cracked section as follows:

$$
\begin{array}{lr}
\text { For columns: } & \mathrm{I}_{\text {eff }}=0.70 \mathrm{I}_{\mathrm{g}} \\
\text { For shear walls: } & \mathrm{I}_{\text {eff }}=0.35 \mathrm{I}_{\mathrm{g}} \\
\text { For beams: } & \mathrm{I}_{\text {eff }}=0.50 \mathrm{I}_{\mathrm{g}}
\end{array}
$$

Where,

$\mathrm{I}_{\mathrm{g}}=$ moment of inertia for the cross section without cracking,

$\mathfrak{I}_{\text {eff }}=$ effective moment of inertia of the cross section (after cracking).

\section{COMPUTER PROGRAM}

In this research a computer program coded in Fortran language is developed to analyze the reinforced concrete buildings under wind and earthquake loads by both codes ECOP-93 and ECOP-201. The program calculates the stiffness of vertical members that resist the lateral loads, the center of mass and the center of rigidity of the building. The base moment, as well as the lateral base shear and the induced additional shear forces due to torsion on each vertical lateral loads resisting element in both directions of the building are calculated. All the results are illustrated graphically by the program to simplify reading the results.

\section{DESIGN EXAMPLE}

The effect of the wind and earthquake by codes ECOP-93 and also ECOP-201 on a 10-story hospital building $18.6 \times 36.6 \mathrm{~m}$ shown in Fig. 3. The main system is flat slabs. The story height is $3 \mathrm{~m}$. The structural system resisting lateral forces consists of columns and shear walls as shown in the figure.

Interior columns are $0.9 \times 0.9 \mathrm{~m}$, exterior columns are $0.6 \times 0.6 \mathrm{~m}$ vertical and horizontal shear walls are $0.4 \times 6.0 \mathrm{~m}$. The building is located in Cairo on a medium soil. The wind pressure is equal to $70 \mathrm{~kg} / \mathrm{m}^{2}$. The live load is $400 \mathrm{~kg} / \mathrm{m}^{2}$, and the average dead load of each repeated floor is $1000 \mathrm{~kg} / \mathrm{m}^{2}$. 


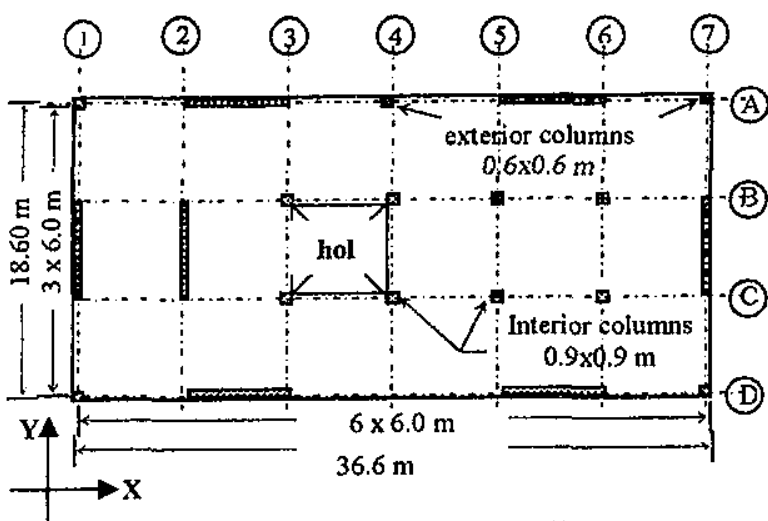

Fig. 3 Plan of the hospital building

Given Data and Results of Code ECOP-201 Wind data

Intensity of wind pressure $\mathrm{q}=1.5 \times 70=112 \mathrm{~kg} / \mathrm{m}^{2}$, $c_{e}($ action $)=0.8$, and $c_{e}$ (suction) $=0.5$

Earthquake data

Seismic zone $=3, \quad$ Spectrum $=$ Type 1 ,

Soil class $=\mathrm{C}, \quad$ Reduction factor $=5.0$

Horizontal damping factor $\eta_{\mathrm{V}}=1.00$,

Vertical damping factor $\eta_{\mathrm{v}}=0.70$, and

Importance factor $\gamma_{\mathrm{I}}=1.40$

Data for horizontal components

Horizontal acceleration. $=0.15 \mathrm{~g}$, Soil value $=1.5$, $\mathrm{T}_{\mathrm{B}}=0.1, \mathrm{~T}_{\mathrm{C}}=0.25$ and $\mathrm{T}_{\mathrm{D}}=1.20$

Eccentricity

$e_{x}=x_{r}-x_{m}=4.099 m, \quad e_{y}=y_{r}-y_{m}=0.0$

$e_{x d}=$ the $\max$ of $e_{x}=x_{r}-x_{m} \pm 0.05 L_{x}=5.93 m$

$e_{y d}=$ the $\max$ of $e_{y}=y_{r}-y_{m} \pm 0.05 L_{y}=0.93 m$

$\mathrm{Jr}=$ Torsion stiffness $=\sum \mathrm{K}_{\mathrm{x}} \mathrm{d}_{\mathrm{x}}^{2}+\mathrm{K}_{\mathrm{y}} \mathrm{d}_{\mathrm{y}}^{2}=5801.5 \mathrm{~m}^{6}$

Wind in $\mathrm{X}$-direction

Max. wind base shear force $\quad F_{b x}=92.077$ ton

Overturning moment $\mathrm{M}_{\mathrm{x}}=1462.406 \mathrm{~m} . \mathrm{t}$

Torsional moment $\mathrm{M}_{\mathrm{bx}}=\mathrm{F}_{\mathrm{bx}} \mathrm{e}_{\mathrm{yd}} \quad=85.632 \mathrm{~m} . \mathrm{t}$

Wind in $\mathrm{Y}$-direction

Max. wind base shear force $F_{b y}=181.185$ ton

Overturning moment $\mathrm{M}_{y}=2877.638 \mathrm{~m} . \mathrm{t}$

Torsional moment $\mathrm{M}_{\mathrm{ty}}=\mathrm{F}_{\mathrm{by}} \cdot \mathrm{e}_{\mathrm{xd}}=1113.93 \mathrm{~m} . \mathrm{t}$

Figure 4 shows the design ultimate loads for vertical resisting element considered by the code. Figure 5 shows the distribution of the ultimate wind pressure in $\mathrm{kg} / \mathrm{m}^{2}$ in both directions according to the Egyptian code.

Earthquake in the in $\mathrm{X}$-and $\mathrm{Y}$-directions

The building was analyzed by the latest code ECOP.

201 and the results were as follows

Period $\mathrm{T}$ for the structure $=0.641$

Design response spectrum SD $(T)=0.044$

Total weight of the structure $\mathrm{W}_{\mathrm{t}}=11670$ ton

Overturnig moment $M_{x}=M_{y}=15055.66$ m.t

Torsional moment $\mathrm{M}_{\mathrm{ty}}=4250.49$ m.t
Torsional moment $\mathrm{M}_{\mathrm{tx}} 666.75 \mathrm{m.t}$

Max. base shear force $F_{b x}=F_{b y}=716.94$ ton

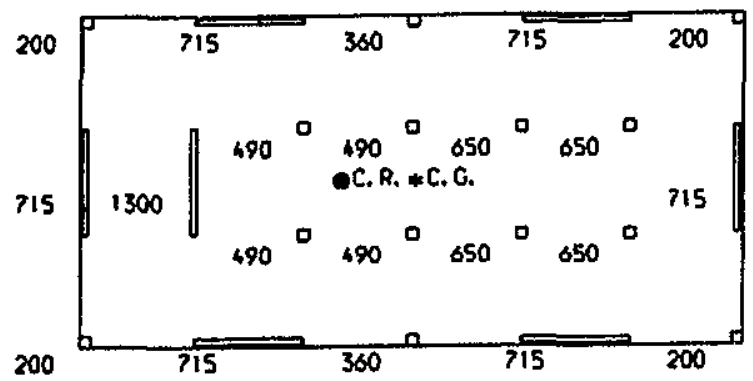

Fig. 4 Vertical design ultimate loads for earthquake $(\mathrm{DL}+0.5 \mathrm{LL})$ in ton
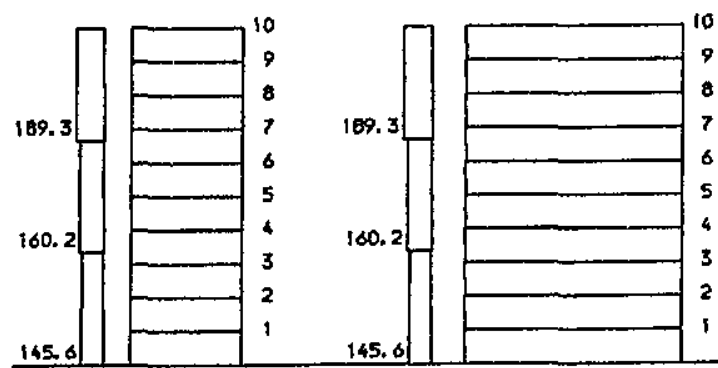

Fig. 5 Wind design lateral forces in $\mathrm{kg} / \mathrm{m}^{2}$

Figure 6 shows the equivalent ultimate static lateral forces on each floor due to earthquake according to the code ECOP-201.

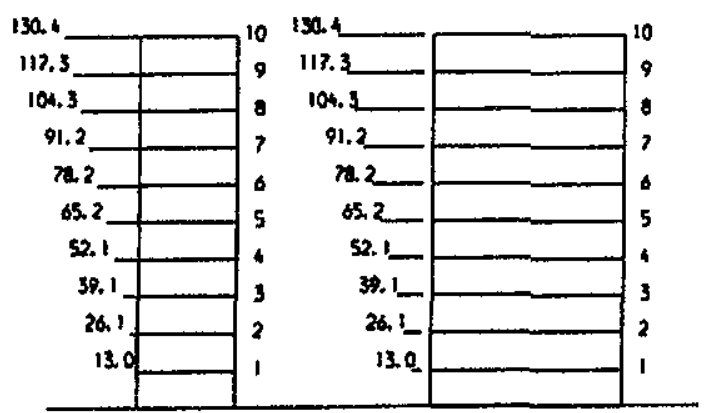

Fig. 6 Seismic ultimate design lateral forces by ECOP-201, in ton

Figures from 7 tol 14 illustrate the results of the wind and earthquake by the code methods for comparisons. Figures 7 and 8 gives the ultimate shear forces on each vertical supporting element in the plan, according to the wind effects in both $\mathrm{X}$ - and $\mathrm{Y}$ directions. Figures 9 and 10 show the ultimate moments for each member in both directions. The analysis of moments based on the cantilever action of the building.

Figures 11 and 12 give the ultimate shear forces for each vertical supporting element in the building according to the earthquake effects by ECOP-201 in both $\mathrm{X}$ - and $\mathrm{Y}$ - directions. Figures 13 and 14 show the ultimate moments for each member in both directions. 
Nageh N. Meleka, "Comparison Between the Design Lateral Loads on R.C. High Rise Buildings According ..."

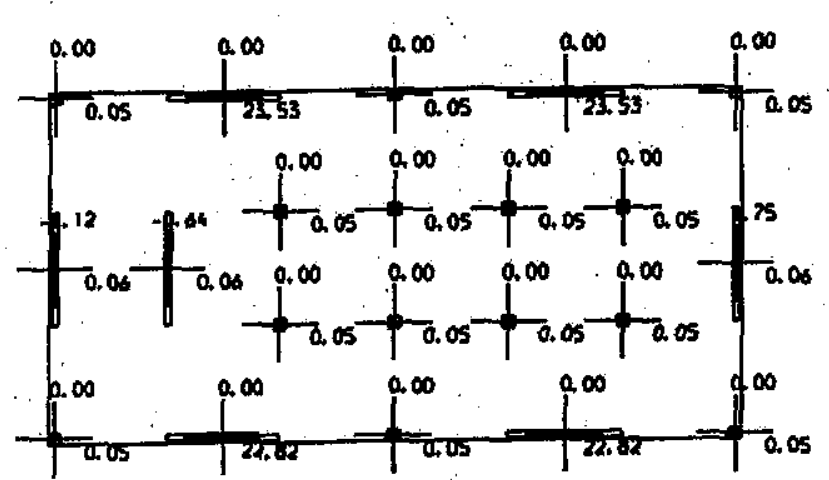

Fig. 7 Ultimate base shear forces due to wind in $\mathrm{X}$-direction in ton

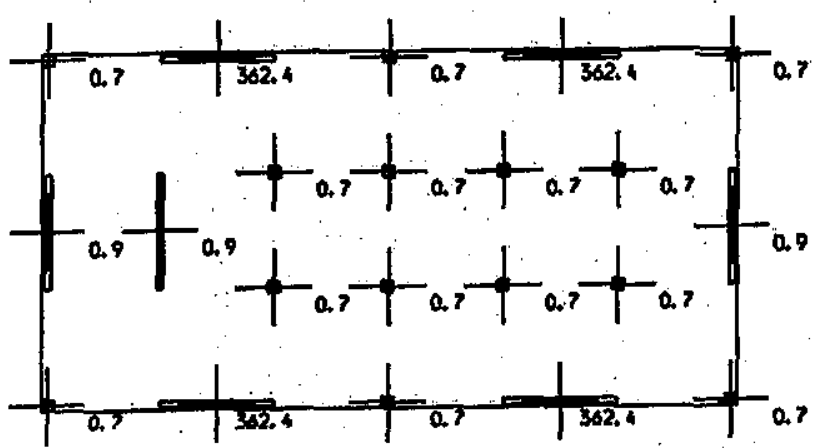

Fig. 9 Ultimate moments at the base due to wind in $\mathrm{X}$ - direction (in $\mathrm{m}, \mathrm{t}$ )

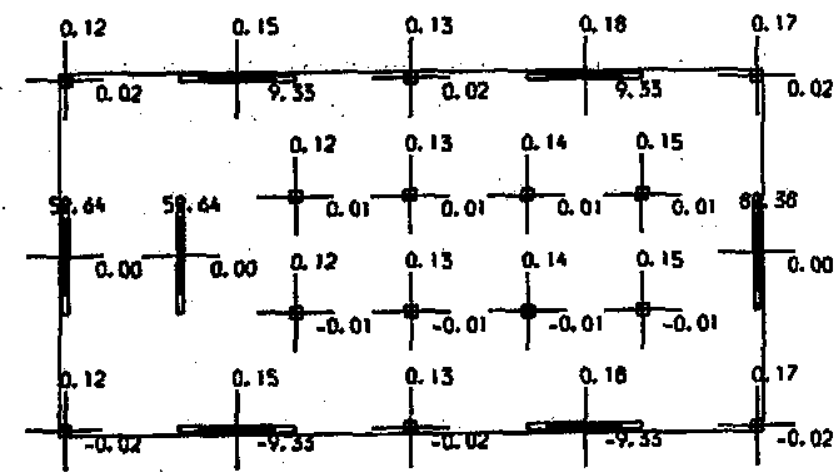

Fig. 8 Ultimate base shear forces due to wind in $\mathrm{Y}$-direction in ton

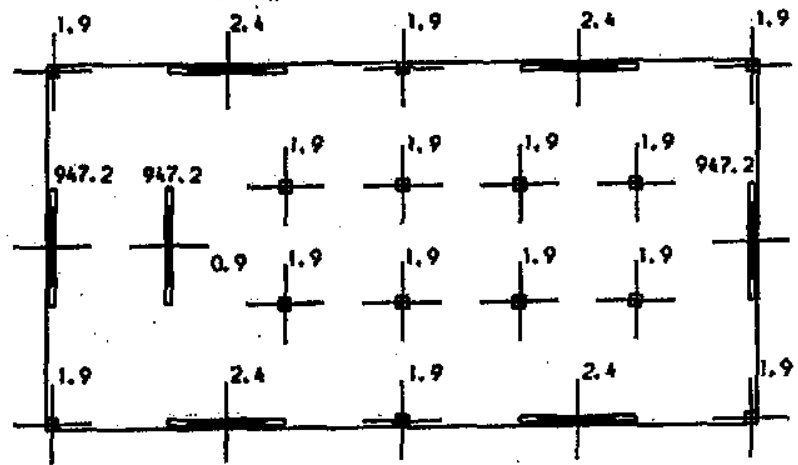

Fig. 10 Ultimate moments at the base due to wind in $\mathrm{Y}$-direction (in $\mathrm{m} . t$ )

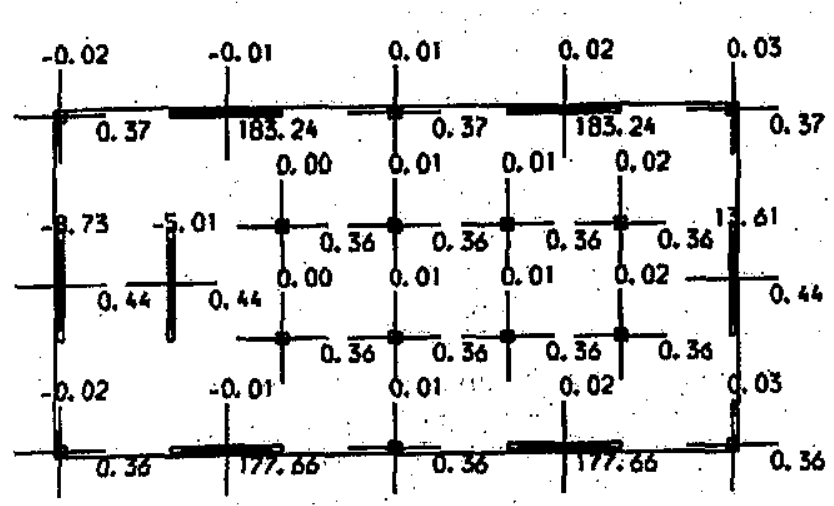

Fig. 11 Utimate base shear forces due to earthquake in $\mathrm{X}$-direction in ton (ECOP-201)

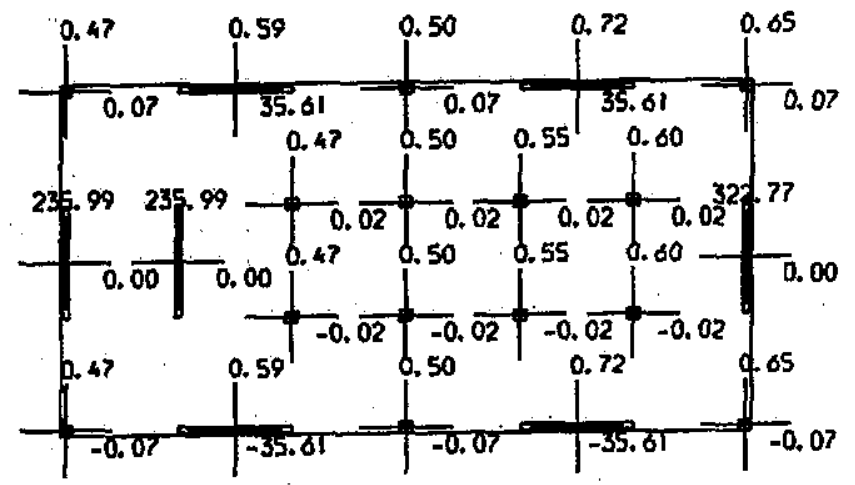

Fig. 12 Ultimate base shear forces due to earthquake in $\mathrm{Y}$-direction in ton (ECOP-201)

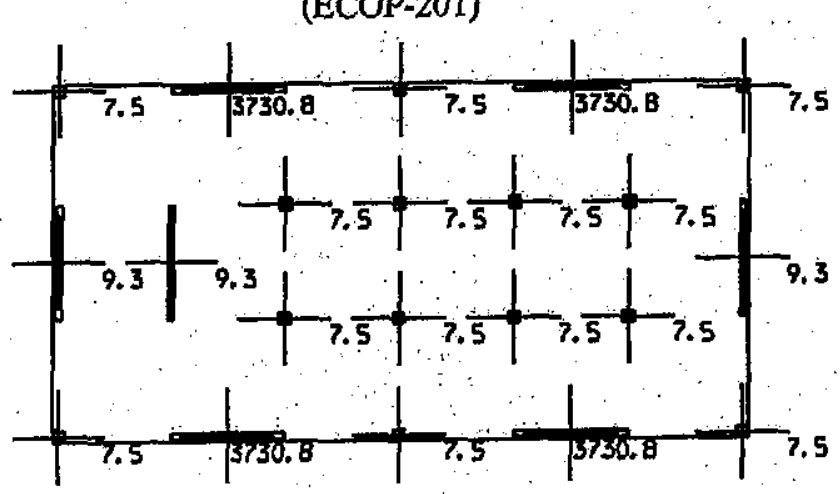

Fig. 13 Ultimate moments at the base due to earthquake in $\mathrm{X}$ - direction in $\mathrm{m} . \mathrm{t}$ (ECOP-201)

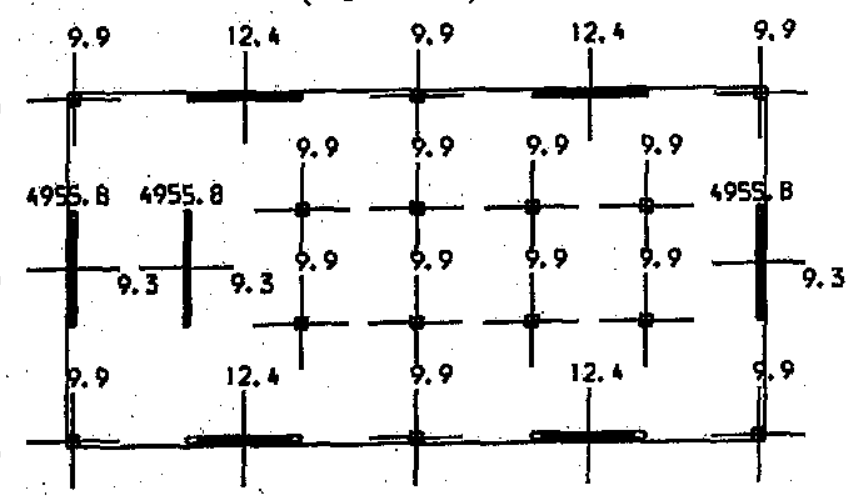

Fig. 14 Ultimate moments at the base due to earthquake in $\mathrm{Y}$ - direction in m.t (ECOP-201) 
From these figures, it is shown that the values of the base shear results from the earthquake are more than three times the effect of the wind in Y-direction, while the moments in the same direction are increased by more than four times.

\section{Data and Results of Code ECOP-93}

\section{Wind analysis}

The previous numerical example is reanalyzed according to the code of practice ECOP-93 to illustrate and compare the results.

The new code ECOP-201 has no changes in the analysis of wind pressure with respect to the previous one. The results of the wind analysis for both codes are the same as before.

Figure 15 shows the design ultimate loads considered in the code. It is noted that the previous code neglect the live loads less than $500 \mathrm{~kg} / \mathrm{m}^{2}$, while the new code adds $50-100 \%$ from the live loads according to the function of the building.

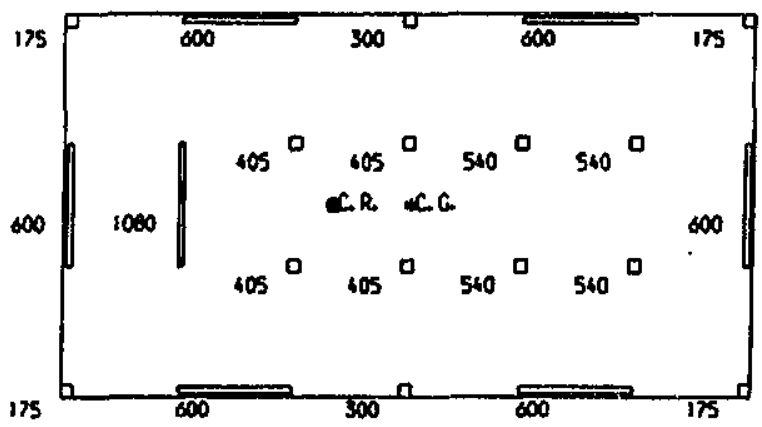

Fig. 15 Vertical design ultimate loads for earthquake (DL) in ton

Earthquake data

Zone factor $Z=0.20$,

Importance factor $\mathrm{I}=1.25$,

Structural system factor $K=1.0$, and

Soil factor $\mathrm{S}=1.15$.

$e_{x}=x_{r}-x_{m}=4.099 m, \quad e_{y}=y_{r}-y_{m}=0.0$

$e_{x d}$ is the miax of

$e_{x}=x_{r}-x_{m} \pm 0.05 L_{x}$ and $e_{x}=1.5\left(x_{r}-x_{m}\right)$

and $e_{y d}$ is the max of

$e_{y}=y_{r}-y_{m} \pm 0.05 L_{y}$ and $e_{y}=1.5\left(y_{r}-y_{m}\right)$

$\mathrm{e}_{\mathrm{xd}}=6.15 \mathrm{~m}, \mathrm{e}_{\mathrm{yd}}=1.93 \mathrm{~m}$

$\mathrm{J}_{\mathrm{r}}=$ Torsion stiffness $=\sum \mathrm{K}_{\mathrm{x}} \mathrm{d}_{\mathrm{x}}^{2}+\mathrm{K}_{\mathrm{y}} \mathrm{d}_{\mathrm{y}}^{2}=5801.55 \mathrm{~m}$

\section{Earthquakes in $\mathbf{Y}$-direction}

Period $\mathrm{T}=\frac{0.09 \mathrm{H}}{\sqrt{\mathrm{B}}}=0.626 \mathrm{sec}$.
Period factor $\mathrm{C}=\frac{1}{15 \sqrt{\mathrm{T}}} \leq 0.12=0.0843$

Base shear force $V_{y}=$ Z.I.K.C.S.W $=236$ ton

Ty $<0.7 \mathrm{sec}$ then force at the top $F_{t}=0.0$

Overturning moment at the base $\mathrm{M}_{\mathrm{y}}=4964.918 \mathrm{~m} . \mathrm{t}$

Torsional moment $\mathrm{M}_{\mathrm{ty}}=1454.065 \mathrm{~m} . \mathrm{t}$

Earthquakes in $\mathrm{X}$-direction

Period $\mathrm{T}=0.4463 \mathrm{sec}$.

Period factor $\mathrm{C}=0.0998$

Base shear force $\mathrm{V}_{\mathrm{x}}=$ Z.I.K.C.S.W $=280$ ton

Ty $<0.7 \mathrm{sec}$ then force at the top $F_{t}=0.0$

Overturning moment at the base $\mathrm{M}_{\mathrm{x}}=5880.362 \mathrm{m.t}$

Torsional moment $\mathrm{M}_{\mathrm{tx}}=260.416 \mathrm{~m} . \mathrm{t}$

Figure 16 shows the distribution of earthquake forces in $\mathrm{kg} / \mathrm{m}^{2}$ in both directions according to the Egyptian code, ECOP -93 by the equivalent static load method.
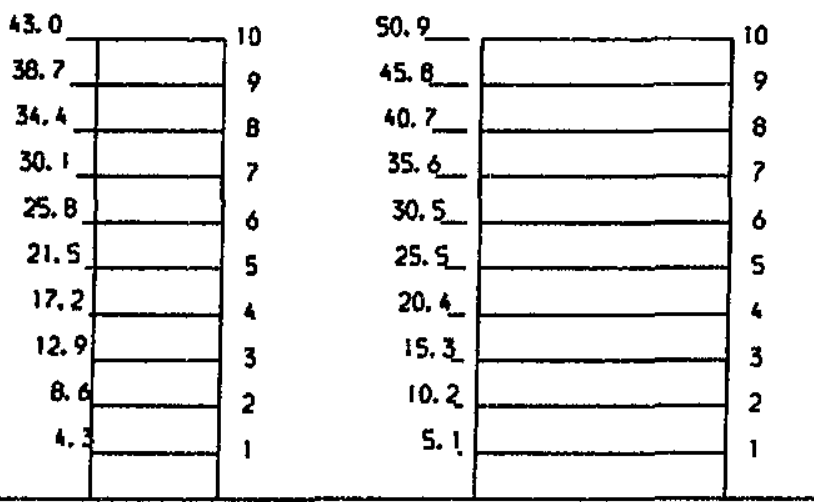

Fig.16 Seismic ultimate design lateral forces in ton

Figures 17 and 18 gives the ultimate shear forces at each vertical supporting elements in the building according to the earthquake effects in both $\mathrm{X}$ - and $\mathrm{Y}$ directions. Figures 19 and 20 show the ultimate moments for each member in both directions.

From Figs. 8 and 18, and by comparing the results, it is noted that the values of the shear base result from code ECOP-93 for earthquakes are more than about $30 \%$ of the effect of the wind in Y-direction, while the moments in the same direction were increased by about $70 \%$ as shown in Figs. 10 and 20.

The values of the shear forces on the base of shear walls that results by the new code ECOP-201 were about 3 times the forces from code ECOP-93 and about 4 times the forces from wind.

Figures 21 and 22 compare the results of wind and earthquake by different codes in the $\mathrm{x}$ - and $\mathrm{Y}$ directions. Figure 21 compares the base shears, and Fig. 22 compares the overturning moments. It is shown that the present codes ECOP-201 gives high values with respect to the previous one. The total 
base shear resulted from earthquake calculations was constant in both $\mathrm{X}$ - and $\mathrm{Y}$ - directions in the present code while it was different in the previous code ECOP-93.
Wind pressure increases on the face of the long side of the building more than the smaller sides, the differences are proportioned with the increase of the exposed area.

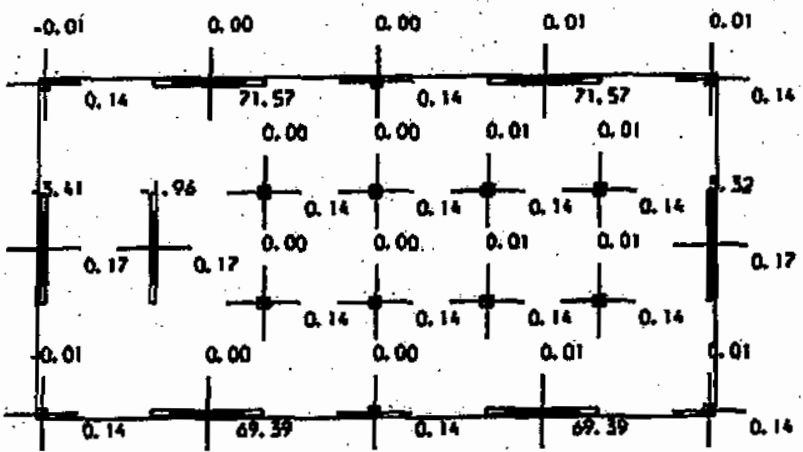

Fig. 17 Ultimate base shear forces due to earthquake in $\mathrm{X}$ - direction in ton (ECOP-93)

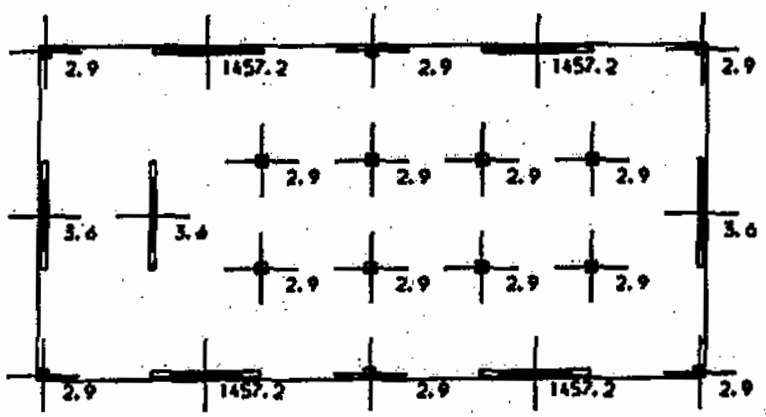

Fig. 19 Ultimate moments at the base due to earthquake in X-direction in m.t (ECOP-93)

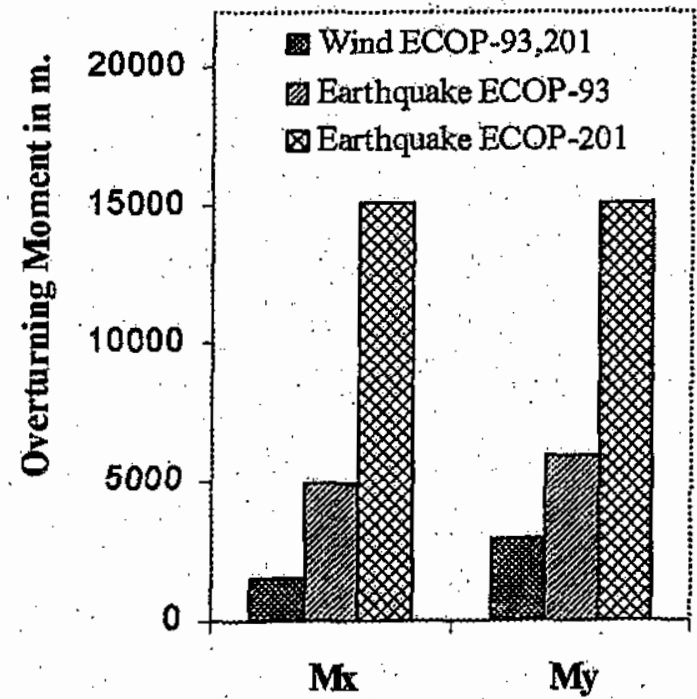

Fig. 22 Comparison between wind and earthquake overturning moments in $X$-and $Y$-directions in $m . t$

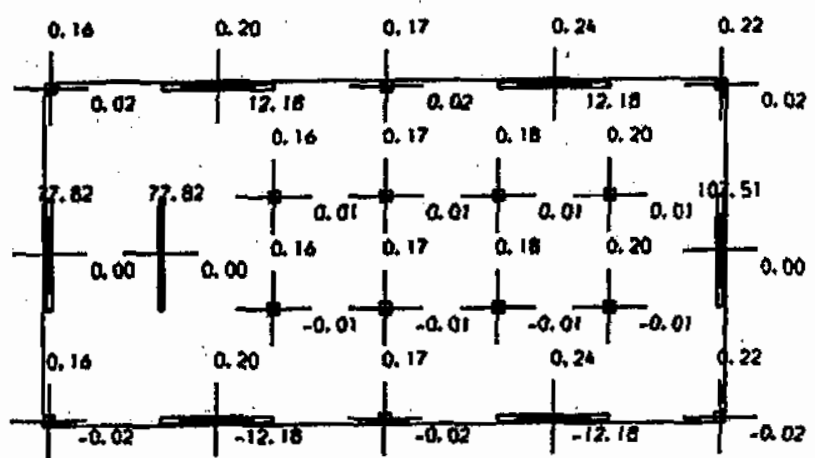

Fig. 18 Ultimate base forces due to earthquake in $\mathrm{Y}$-direction in ton (ECOP-93)

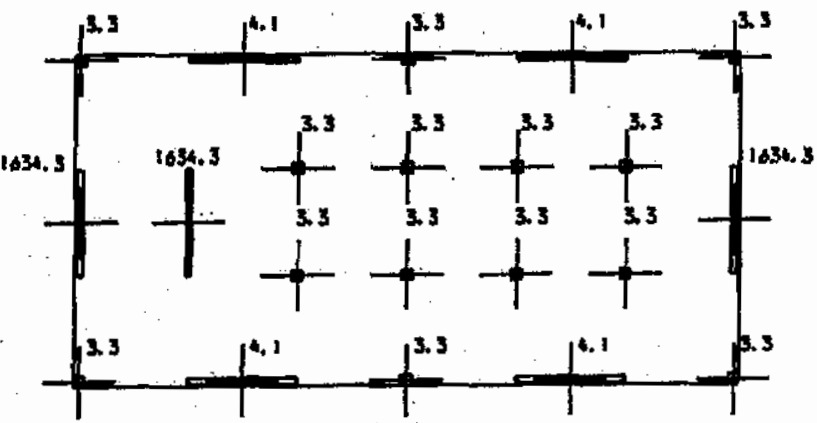

Fig. 20 Ultimate moments at the base due to earthquake in $\mathrm{Y}$ - direction in $\mathrm{m} . \mathrm{t}$ (ECOP-93)

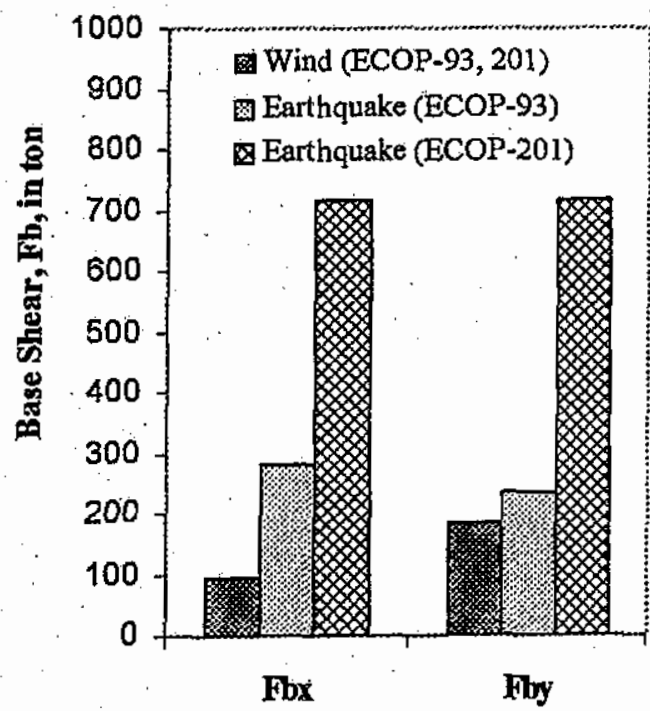

Fig. 21 Comparison between wind and earthquake base shear forces in $\mathrm{X}$ - and $\mathrm{Y}$-directions in $\mathrm{m} . \mathrm{t}$ 


\section{COMPARISONS BETWEEN THE MINIMUM AND THE MAXIMUM BOUNDARIES}

The previous example shown in Fig. 3 is resolved many times with different factors to represent the following cases:

1- Twenty buildings with different number of floors are analyzed to show the effect of building height on the analysis of both wind and earthquake. The height of the buildings ranged from $3.0 \mathrm{~m}$ to $60.0 \mathrm{~m}$ to cover short, mid and high rise buildings.

2-To show the boundaries of the minimum and the maximum effect of both wind and earthquake, the thirty buildings are analyzed for two cases assuming the given factors in Table 1. Buildings are analyzed for both ECOP-93 and ECOP-201 for both response spectrum Type 1 and Type 2.

Figure 23 shows the relation between number of floors of the building and the shear forces at the base for both wind and earthquake when they act normal to the long direction of the building (Fig. 3), and Fig. 24 shows the effect of response spectrum Type 1 and Type 2 on the relation between the number of floors and the base shear of the buildings. Figure 25 shows the relationship between the number of floors and overturning moments induced from wind and earthquakes.

In Case 1, when minimum design factors are considered in the analysis of tall buildings, wind is somewhat more effective than earthquake, while earthquake is found to be more effective for short buildings.

The wind effect increases rapidly when the height of the building increases. The shear forces and the moments at the base normal to the long direction are more than that on the short direction, while for earthquake the forces on long directions are less than the short direction in case of ECOP-93 and constant in both directions for ECOP-201.

In Case 2, the effect of earthquake by code ECOP201 is very large because it depends on many design factors which leads to uneconomic results. The difference between wind and earthquake results decreases when the height of the building increases. In Case 1, for buildings with 10 and 20 floors, the values of the base shear from code ECOP-201, Type 1 , were about 5.8 and 4.9 times the values resulted from ECOP-93 respectively, while the values were about 2.0 and 1.04 times the wind results respectively.

In Case 2, the values of base shear are increased for building 10 and 20 floors, for ECOP-201, Type 1 , and were about 3.6 and 3.0 times the values of ECOP-93 respectively whereas the values were about 8.7 and 4.4 times the wind results.

In Case 1, when applying the response spectrum Type 2 for buildings 10 and 20 floors, the values of the base shear forces resulted from code ECOP-201 were about 7.9 and 7.8 times the values resulted from ECOP-93 while these values were about 2,8 and 1.66 times the wind respectively.

In Case 2, when applying the response spectrum Type 2 for buildings 10 and 20 floors, the values of the base shear forces resulted from code ECOP-201 were about 4.9 and 5.1 times the values resulted from ECOP-93 respectively.

Table (1) Factors considered in the analysis

\begin{tabular}{|c|c|c|c|}
\hline & Variable Factors & $\begin{array}{c}\text { Case } 1: \\
\text { Minimum } \\
\text { effect }\end{array}$ & $\begin{array}{c}\text { Case 2: } \\
\text { Maximum effect }\end{array}$ \\
\hline Wind ECOP93,201 & Intensity of wind pressure & $50 \mathrm{~kg} / \mathrm{m}^{2}$ & $90 \mathrm{~kg} / \mathrm{m}^{2}$ \\
\hline \multirow{4}{*}{ Earthquake ECOP-93 } & Zone factor & 0.1 & 0.3 \\
\cline { 2 - 4 } & Structural system factor & 0.67 & 1.33 \\
\cline { 2 - 4 } & Importance factor I & 1.0 & 1.25 \\
\cline { 2 - 4 } & Soil factor & 1.0 & 1.3 \\
\hline \multirow{3}{*}{$\begin{array}{c}\text { Earthquake ECOP-201 } \\
\text { Type (1) Spectrum }\end{array}$} & Design ground acceleration & $\mathrm{a}_{\mathrm{g}}=0.1 \mathrm{~g}$ & $\mathrm{a}_{\mathrm{g}}=0.25 \mathrm{~g}$ \\
\cline { 2 - 4 } & Response modification $\mathrm{R}$ & 5.0 & 4.5 \\
\cline { 2 - 4 } & Importance factor $\gamma_{\mathrm{I}}$ & 1.0 & 1.40 \\
\cline { 2 - 4 } Earthquake ECOP-201 \\
Type (2) Spectrum & Soil factor & $\mathrm{A}$ & $\mathrm{D}$ \\
\hline & Design ground acceleration & $\mathrm{a}_{\mathrm{g}}=0.1 \mathrm{~g}$ & $\mathrm{a}_{\mathrm{g}}=0.25 \mathrm{~g}$ \\
\cline { 2 - 4 } & Response modification $\mathrm{R}$ & 4.5 & 5.0 \\
\cline { 2 - 4 } & Importance factor $\gamma_{\mathrm{I}}$ & 1.0 & 1.40 \\
\cline { 2 - 4 } & Soil factor & $\mathrm{A}$ & $\mathrm{D}$ \\
\hline
\end{tabular}




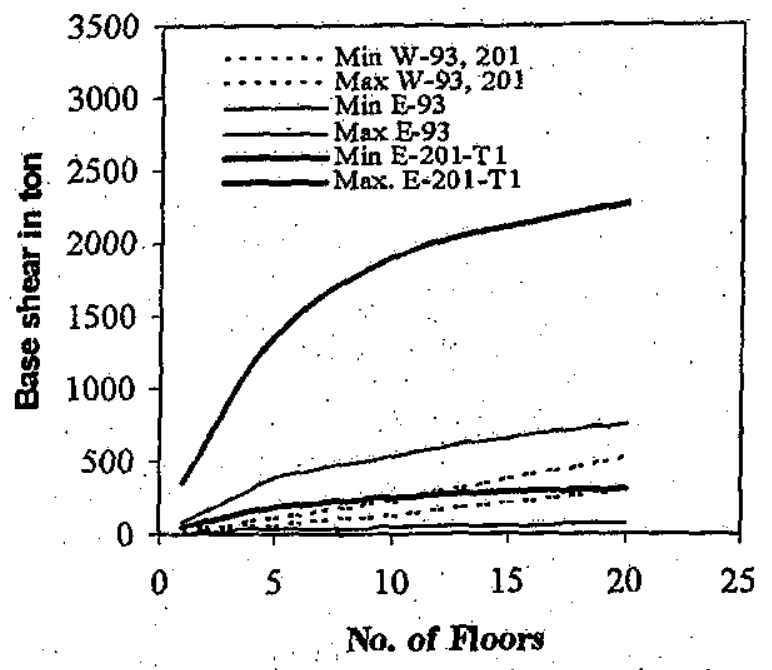

Fig. 23 Comparison between wind and earthquake loads in $\mathrm{Y}$ direction

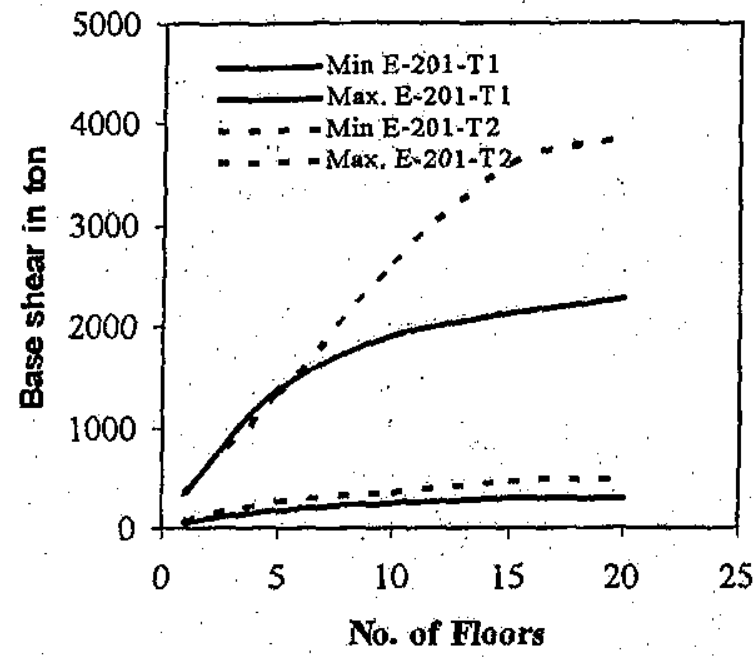

Fig. 24 Base shear by ECOP-201 for both Type (1) and Type (2)

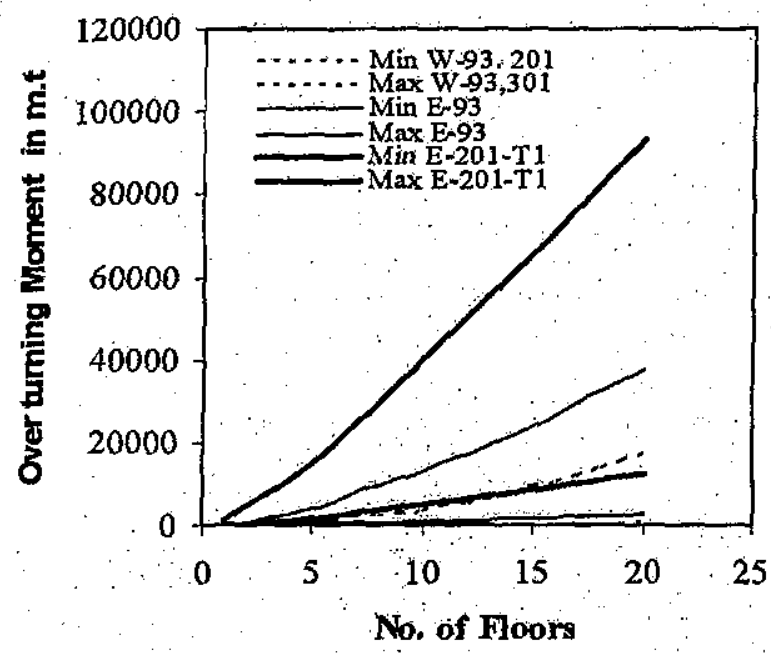

Fig. 25 Comparison between overturning moments in $Y$ direction

\section{CONCLUSIONS}

1- Wind is more effective than earthquake for tall buildings when minimum design factors are considered, and earthquake is found to be more effective for short buildings. The wind effect increases rapidly when the height of the building increases.

2-In seismic code, the variation of the results is more than that of the wind analysis because of depending on many design factors. One of the most important factors is the kind of the structural system. Ductile frames are recommended for tall building or when earthquake govern the design.

3. For building system consists of shear walls and frames, the presence of shear walls dominates the calculation of lateral forces. The relative crosssectional areas of the columns and shear walls in the design example was about 1:2.25:6.7 respectively, while lateral forces distributed by about $1: 1.2: 460$. It can be considered that the shear walls almost resist all lateral loads and column resistance can be neglected.

4- For all cases of study in this research, the results of the new code ECOP-201 for response spectrum Type 1 were higher than the results of wind, and ranged from 1.0 to 8.0 times the values of the wind. The variation depends on the factors affecting the seismic design. However seismic analysis will always governs the design except for cases when seismic factors are small and wind factors are high. 5- In this research, the results of the new code ECOP201 when response spectrum Type 1 is applied were higher than that of ECOP-93 from 3 to 5 times and for Type 2 , the values ranged from 4 to 8 times. These variations depend on the factors affecting the seísmic design.

6- Although the new code ECOP-201 provides more resistance and safety against seismic loads, The costs of constructions will be increased. Most National building'codes identify some factors according to the boundary conditions of each building considered in the analysis to provide the life safety, but not to insure against damage. A realistic estimate for these factors is important; however the cost of construction and therefore the economic viability of the project is essential.

\section{SYMBOLS}

$\mathrm{a}_{\mathrm{g}}: \quad$ Design ground acceleration

CM: Center of mass of the building

CR: Center of rigidity of the building

$c_{e:}$ Pressure or suction distribution factor

e: : Eccentricity between CM and CR

ed: Design eccentricity

$\mathrm{H}$ : Height of the building

I : moment of inertia for the cross section without cracking, 
Ioff effective moment of inertia of the cross section (after cracking)

$J_{\mathrm{r}}: \quad$ Torsional stiffness

$\mathrm{k}$ : $\quad$ Factor of exposure

$\mathrm{K}_{\mathrm{x}}, \mathrm{K}_{\mathrm{y}}:$ Stiffness of member resisting lateral load in $\mathrm{X}$ and $\mathrm{Y}$ directions respectively

$P_{\circ}: \quad$ External design wind pressure

q: Original wind pressure

$\mathrm{R}$ Response modification (force reduction) factor

S: $\quad$ Soil factor and

$S_{d}\left(T_{l}\right)$ : Design elastic response spectrum

$\mathrm{T}_{\mathrm{I}}$ : Fundamental period of the building in sec.

$T_{B}, T_{C}, T_{D}$ : Factors according to subsoil class

$\mathrm{W}: \quad$ Total building weight over the foundations

$Z$ : $\quad$ zone factor

$\eta$ : Horizontal damping factor

$\eta_{v}$ : Vertical damping factor

$\lambda$ : Correction factor

$\gamma_{\mathrm{I}}:$ Importance factor

\section{REFERENCES}

[1] "Egyptian Code of Practice for Calculating Loads and Forces in Structural and Building Works", Research Center for Housing, Building and Physical Planning, 1993.

[2] "Egyptian Code of Practice for Calculating Loads and Forces in Structural and Building Works", Research Center for Housing, Building and Physical Planning, Code 201,1993.
[3] "Egyptian Code of Practice for Design and Construction on Reinforced Concrete Structures", Research Center for Housing, Building and Physical Planning, Code 201, 2003.

[4] Farzad Naeim, "The Seismic Design Handbook", Van Nostrand Reinhold, New York, 1989.

[5] Comite Euro-International $\mathrm{Du}$ Beton, " RC Frames under Earthquake Loading", State of the Art Report, Tomas Telford, 1998.

[6] Meleka, N.N, and Tayel, M.A., "Analysis of Concrete Structures Subjected to Wind and Earthquake Loads Using the Egyptian Code Provision", Second Conference of Egyptian Rural Development, Menoufiya University, 27 April 1999.

[7] Meleka, N.N., "Effects of Shear Walls Dimensions and Locations for Resisting Wind and Earthquake Loads by the Egyptian Code", The Eighth Arab Structural Engineering Conference, Cairo University, 21-23 October, 2000.

[8] Essam A.E., "Effects of Connection Details implementation on Seismic Behavior of Mid and High-Rise RC Buildings", Eleventh International Colloquium on Structural and Geotechnical Engineering, Ain Shams University, Faculty of Eng., Department of Structural Engineering, 1719 May 2005 